\title{
Evaluation of Haematological and Serum Biochemical Characteristics of Annona muricata (Sour Sop) Leaf Extract on Broiler Birds
}

\author{
*Jiwuba, Peter-Damian Chukwunomso ${ }^{1}$, Kuka, Tar Timorthy ${ }^{1}$, Kadurumba, Ogechi \\ Evangeline. $^{2}$ Nwachukwu, Cynthia Ozioma ${ }^{3}$ \\ ${ }^{1}$ Department of Animal Health and Production Technology, Federal College of Agriculture, Ishiagu, Ebonyi State, \\ Nigeria. \\ ${ }^{2}$ Department of Animal Science and Technology, Federal University of Technology, Owerri, Nigeria. \\ ${ }^{3}$ Departmentof Animal Production Technology, Federal College of Agriculture, Ishiagu, Ebonyi State, Nigeria. \\ *Corresponding Author: Jiwuba, Peter-Damian Chukwunomso, Department of Animal Health and \\ Production Technology, Federal College of Agriculture, Ishiagu, Ebonyi State, Nigeria.
}

\begin{abstract}
A 48 day nutritional experiment was conducted to determine the haematological and serum biochemistry characteristics of broilers fed Annona muricata leaf extract. A total of 96 day old Abor acre broiler birds were randomly divided into four experimental groups of 24 birds per treatment and replicated three times with 8 birds per replicate in a completely randomized design (CRD). $T_{1}$ was the control and fed water without the test ingredient while $T_{2}, T_{3}$ and $T_{4}$ were given Annona muricata leaf extract at different concentrations $(20,40$ and $60 \mathrm{mls})$ per litre of water respectively. At the end of the trial, blood samples were collected from the birds via marginal wing vein and examined for biochemical parameters such as total protein, creatinine, and some important enzymes of nutritional interest such as; alkaline phosphatase (ALP), aspartate amino transferase (AST), and alanine amino transferase (ALT). Haematological parameters were also analyzed for white blood cell, Haemoglobin, red blood cell, mean corpuscular volume, mean corpuscular haemoglobin concentration, packed cell volume and mean corpuscular haemoglobin. Significant differences $(P<0.05)$ were observed in packed cell volume and mean corpuscular haemoglobin, while the other haematological parameter were similar $(P>0.05)$ across the treatment groups. The serum biochemical parameters differed $(P<0.05)$ significantly across the treatment groups. Treatment three $(40 m l s$ inclusion of Annona muricata leaf extract) performed better than other treatments. This indicated that, Annona muricata leaf extract at $40 \mathrm{mls}$ per one litre of drinking water for broiler birds had the best performance and therefore was recommended for broiler production.
\end{abstract}

Keywords: Medicinal plants, phytogenics, sour sop, poultry, leaf extract and blood profile

\section{INTRODUCTION}

Phytobiotic compounds are generally used in poultry nutrition for promoting growth and health in animals. The ban of use of antibiotics as growth promoters by European Union, due to its cause of not only cross-resistance, but also due to the risk of possible drug multiple resistances in human pathogenic bacteria has necessitated the need for alternative growth promoters. Recently, feeds free from chemical additives are increasingly used in poultry nutrition. Consequently, the animal feed manufacturers are exposed to increasing consumer pressure to reduce the use of antibiotic growth promoters as feed additive and find alternatives to antibiotic growth promoters in poultry diets [1]. The phytobiotics used as growth promoters are biological additives like blends of herbs or plant extracts. The bioactive ingredients such as alkaloids, bitters, flavonoids, glycosides, mucilage, saponins and tannins are the plant extracts commonly employed as feed.

Recently, a number of scientific studies have concentrated on the bactericidal and bacteriostatic effects of various herbs and plant extracts. Some have been found to inhibit the growth of either $E$. coli or Staphylococcus aureus or both [2]. It has also been reported[3] that the appetizing and stimulating activity of herbs and plant extracts on animal digestive and immune system could beneficially improve the performance and general health of livestock and poultry. The effects could 
be due to increase production of digestive enzymes, enhanced gut health and improved utilization of digestive products.

In recent years, there has been a gradual interest in the use of medicinal plants $[3,4,5]$ in developing and developed countries because of their ethno-veterinary properties when compared to synthetic drugs. One of such medicinal plant is Annona muricata. Annona muricata is a multipurpose fruit bearing tree belonging to the Annonaceae family and of tropical origin. It has been reported to rich in enzymes (pectinase, catalase, and peroxidase), protein and amino acids (glutamic acid, aspartic acid, serine glycine,alanine, citrulline, cystine,arginine, and lysine), minerals, vitamins and sugar. The leaves been reported to have multipurpose medicinal properties [6] such as sedative, cytotoxic, antileishmanial, wound healing, antimicrobial, anticarcinogenic, genotoxic and immunosuppressive activity. Annona muricata has been reported to protect the structural integrity of hepatocytic cell membrane or regeneration of damaged liver cells [7]. Nutrient composition of A. muricata [7] has been documented, but not much has been reported on the use of $A$. muricata as feed ingredient source for poultry, especially as an extract on broiler blood profile. Therefore, this experiment was carried out to determine the haematological indices and toxicity effect of A. muricata leaf extract on broilers through some serum biochemical studies.

\section{Materials AND Methods}

Location of the experimental site: This research work was carried out at the poultry unit, Federal College of Agriculture, Ishiagu, Ivo Local Government Area of Ebonyi State, Nigeria. The location of the experimental site was situated at latitude $5^{0} 48^{1}$ north of the equator and longitude $7^{0} 31^{1} \mathrm{E}$ and has an average rainfall of $1655 \mathrm{~mm}$ and a prevailing temperature of $28.5^{\circ} \mathrm{C}$ with average relative humidity of $88 \%$ [8].

Sources and Processing of Experimental materials: The experimental materials (Annona muricata) leaves were sourced within and nearby communities in Ishiagu. The leaves were collected, separated from the stalk, air dried at room temperature after which they were milled to fine powder. $50 \mathrm{~g}$ of the Annona muricata powder was dissolved in $100 \mathrm{ml}$ of hot water, allowed to soak for 8 hours. The mixture was filtered to produce $5 \%$ infusion which was stored in a freezer for administration in drinking water.

Experimental diet: The birds were fed with a formulated dietad lib. Annonamuricata leaf extract was added at $0,20,40$ and $60 \mathrm{ml} /$ liter of drinking water representing $\mathrm{T}_{1}, \mathrm{~T}_{2}, \mathrm{~T}_{3}$ and $\mathrm{T}_{4}$ respectively. Birds on treatment one received synthetic antibiotics instead of the leaf extract.

Experimental birds and management: A total of ninety six (96) Abor acre birds were purchased from a reputable farm in Enugu, Enugu state, Nigeria for this experiment. The birds were randomly assigned to four treatment group. Each treatment was replicated three (3) times with eight (8) birds each in a complete randomized design (CRD) and given the extract for 48 days. Before the arrival of the birds, the brooder house was thoroughly swept, cleaned, disinfected and littered with wood shaving. The brooder house was heated to $32.3^{0} \mathrm{C}-33.3^{\circ} \mathrm{C}$. Fresh water containing glucose was given to combat stress and enable them gain instant energy. Feed and water was supplied ad-libitum to the birds. Birds were subjected to routine vaccination and broiler management procedure.

Sample collection: At the end of the experiment, the birds were bled through the marginal wing vein for serum biochemical and haematological studies. $4 \mathrm{mls}$ of blood was collected with a hypodermic sterile needle and syringe. An initial $2 \mathrm{ml}$ was collected over labeled sterilized bottle containing EDTA (Ethylene Diamine Tetracetic Acid) which prevented the blood from coagulating and used for haematological studies. $2 \mathrm{ml}$ was also collected over anti coagulant free bottle for serum biochemistry. The following parameters were determined;Pack cell volume, Haemoglobin (HB), White blood cell (WBC), Red Blood Cell (RBC), Mean Corpuscular Haemoglobin Concentration (MCHC), Mean Corpuscular Volume (MCV) were calculated.

Proximate analysis: proximate analysis of different experimental diets and that of the test ingredient was carried out at the College of Animal Science and animal Production, Michael Okpara University of Agriculture, Umudike, Animal Nutrition Laboratory, using the methods of [9].

Data Analysis: Data obtained were analyzed using Analysis of Variance (ANOVA) applicable to a completely randomized design (CRD) [10]. Differences in mean were separated using Duncan Multiple Range Test [11]. 


\section{RESULTS}

The Proximate composition of Annona muricata leaf and the experimental diet is presented in Table 2.The serum biochemistry of broilers fed Annona muricata leaf extract is presented 3 . There were significant $(\mathrm{P}<0.05)$ differences for total protein, aspartate amino transferase (AST), alkaline phosphate (ALP), alanine amino transferase (ALT) and creatinine. All the enzymes studied were significantly $(\mathrm{P}<0.05)$ and numerically higher in the birds fed the control diet in comparison to the birds fed the treatment Annona muricata leaf extract in their water.Similarly, the creatinine value obtained in this study were significantly $(\mathrm{P}<0.05)$ higher in the birds fed the control diet in comparison to the birds fed the treatment Annona muricata leaf extract in their water.The haematological profile of broilers fed Annona muricata leaf extract is presented 4. The white blood cell, haemoglobin, red blood cell, mean corpuscular volume and mean corpuscular haemoglobin concentration were not significant $(\mathrm{p}>0.05)$. The Packed cell volume (PCV) and Mean corpuscular haemoglobin $(\mathrm{MCH})$ were significantly $(\mathrm{P}<0.05)$ influenced by the treatments.

\section{DISCUSSION}

The results obtained for Annona muricata leaf powder showed that the powder have relative high $\mathrm{CP}$ of $17.95 \%$, which was lower than $25 \% \mathrm{CP}$ reported by [12] and [13]. The reported $7.39 \%$ ash in this study is a reflection of high mineral contents preserved in the plant leaf. The ash value however, compared favourably well with the ash values reported for some leafy vegetables commonly consumed in Nigeria such as Occimum graticimum $(8.00 \%)$ and Hibiscus esculentus $(8.00 \%)$. The ether extract, fibre and dry matter values of this study also compared well with $5.95 \%, 95.0 \%$ and $17.80 \%$ for ether extract, dry matter and fibre contents of Occimum graticimumas reported by[14].

Table 1. Percentage composition of experimental diet

\begin{tabular}{|l|l|}
\hline Feed & Ingredients \\
\hline Maize & 52 \\
\hline Soyabean meal & 25 \\
\hline Groundnut cake & 14 \\
\hline Palm kernel cake & 5 \\
\hline Fish meal & 1.0 \\
\hline Lime stone & 1.0 \\
\hline Bone meal & 1.0 \\
\hline Salt & 0.25 \\
\hline Vit./mineral premix & 0.25 \\
\hline Methionine & 0.25 \\
\hline Lysine & 0.25 \\
\hline Total & $\mathbf{1 0 0}$ \\
\hline
\end{tabular}

\section{Calculated composition}

Crude protein (\%) 23.49

Energy (Kcal M.E/kg) 2910.16

Table 2. Proximate Composition of Annona muricata leaf powder

\begin{tabular}{|l|l|}
\hline Nutrients (\%) & Annonamuricata leaf \\
\hline Dry matter & 95.00 \\
\hline Crude fibre & 17.80 \\
\hline Crude protein & 17.15 \\
\hline Ether extract & 5.95 \\
\hline Ash & 7.39 \\
\hline Nitrogen free extract & 46.71 \\
\hline ME (Kcal/kg) & 3762.01 \\
\hline
\end{tabular}

Table 3. Serum biochemistry profile of broilers fed Annona muricata leaf extract

\begin{tabular}{|l|l|l|l|l|l|}
\hline Parameters & $\mathbf{T}_{\mathbf{1}}$ & $\mathbf{T}_{\mathbf{2}}$ & $\mathbf{T}_{\mathbf{3}}$ & $\mathbf{T}_{\mathbf{4}}$ & SEM \\
\hline Total protein(g/l) & $5.3233^{\mathrm{a}}$ & $3.8133^{\mathrm{b}}$ & $3.7487^{\mathrm{b}}$ & $3.5100^{\mathrm{b}}$ & 0.17 \\
\hline Aspartate amino transferase AST & $28.667^{\mathrm{a}}$ & $21.000^{\mathrm{b}}$ & $19.667^{\mathrm{b}}$ & $16.333^{\mathrm{b}}$ & 1.19 \\
\hline Alkaline phosphatase ALP & $108.423^{\mathrm{a}}$ & $95.730^{\mathrm{ab}}$ & $93.863^{\mathrm{ab}}$ & $89.587^{\mathrm{b}}$ & 2.51 \\
\hline Alanine amino transferase ALT & $30.333^{\mathrm{a}}$ & $26.000^{\mathrm{ab}}$ & $23.333^{\mathrm{b}}$ & $21.333^{\mathrm{b}}$ & 1.13 \\
\hline Creatinine (mg/dl) & $1.6233^{\mathrm{ab}}$ & $1.1733^{\mathrm{a}}$ & $1.1600^{\mathrm{ab}}$ & $1.1333^{\mathrm{b}}$ & 0.05 \\
\hline
\end{tabular}

${ }^{\mathrm{a}, \mathrm{b}}$ Means within the same row with different superscripts are significantly different $(\mathrm{P}<0.05)$ 
Evaluation of Haematological and Serum Biochemical Characteristics of Annona muricata (Sour Sop) Leaf Extract on Broiler Birds

Table 4. Haematological profile of broilers fed Annona muricata leaf extract at different inclusion level

\begin{tabular}{|l|l|l|l|l|l|l|}
\hline Parameters & T1 & T2 & T3 & T4 & SEM & *Normal range* \\
\hline White blood cell $\left(\times 10^{12} / \mathrm{mm}^{3}\right)$ & 13.47 & 20.57 & 21.83 & 19.17 & 4.44 & $9.7-31.0$ \\
\hline Haemoglobin $(\mathrm{gldl})$ & 11.50 & 10.33 & 12.17 & 10.40 & 0.39 & $7.5-13.1$ \\
\hline Red blood cell $\left(\mathrm{x} 10^{6} / \mathrm{mm}^{3}\right.$ & 2.62 & 2.51 & 2.73 & 2.48 & 0.09 & $1.5-3.9$ \\
\hline Packed cell volume $(\%)$ & $40.90^{\mathrm{ab}}$ & $37.47^{\mathrm{ab}}$ & $44.37^{\mathrm{a}}$ & $37.10^{\mathrm{b}}$ & 1.21 & $26.0-45.2$ \\
\hline Mean corpuscular volume $(\mathrm{fl})$ & 107.27 & 109.97 & 108.10 & 100.97 & 1.80 & $100.0-128.0$ \\
\hline Mean corpuscular haemoglobin $(\mathrm{Pg})$ & $34.10^{\mathrm{a}}$ & $31.23^{\mathrm{b}}$ & $36.07^{\mathrm{a}}$ & $33.63^{\mathrm{ab}}$ & 0.43 & $25.3-33.4$ \\
\hline Mean corpuscular haemoglobin conc. $\%$ & 28.67 & 27.50 & 28.33 & 28.33 & 2.09 & $25.3-32.5$ \\
\hline
\end{tabular}

${ }^{\mathrm{a}, \mathrm{b}}$ Means within the same row with different superscripts are significantly different $(\mathrm{P}<0.05)$

The difference and similarities of the proximate composition of the test ingredient with the other leafy vegetables may be attributed to different plant species, soil type, season of harvest and age of the leaves during harvest.

Increase in serum enzymes would signify necrosis or myocardial infarctions [15] or hepatic metabolism[16] which is all indicators of poor protein quality of the diets. This tends to suggest that the quality of protein [17] in test diets was better than that of the control diet. The level of serum creatinine signals the extent of muscle wastage [18].This results, however, suggests that there were no muscle wastages and that the birds did not survive at the expense of body of body reserve. This is a good indication that the dietary protein was well utilized by the birds within each treatment group [19]. The values for serum protein obtained in this study compared well with the serum protein (4.50$6.54 \mathrm{~g} / \mathrm{l})$ reported by [20] but lower than 8.32 to $8-70 \mathrm{~g} / \mathrm{dl}$ reported by [21] and higher than 2.04 $2.88 \mathrm{~g} / \mathrm{dl}$ reported by [22].Higher values are an indicative of enzyme hydrolysis of dietary proteins and explained that the blood pool serves as a major source of amino acids needed for the synthesis of proteins $[23 ; 21]$.

The values for all the haematological parameters evaluated however fell within the normal physiological range for apparently healthy broilers according to [24]. The Packed Cell Volume (PCV) values (37.10-44.37\%) obtained in this study fell within the normal range of $26.0-45.2 \%$ for apparently healthy broilers according to [24]. T3 had the highest value of $44.37 \%$ while T4 had the lowest value of $37.10 \%$. The normal range of PCV observed in this study suggests absence of toxic factor like haemagglutamin and anemia which causes reduced oxygen carrying-capacity of blood, dizziness, leg cramps and rapid heartbeat [25]. PCV values obtained for all treatment groups were within normal range for broilers which is an indication that the treatment diets were nourishing and nontoxic and influenced adequate blood supply. $\mathrm{MCH}$ concentration which falls within the reference values 25.3-33.4 x1012/L for normal adult chicken as reported by [24]. This implies that the feed value of the diets was adequate and the Annona muricata leaf extract did not reduce its nutritional quality.

\section{CONCLUSiON}

The inclusion of Annona muricta leaf extract in the drinking water of broiler as a replacement of antibiotics resulted in significant improvement in the blood profile of the birds. The results of this study showed that Annona muricata leaf extract in broiler diets (water) could be effectively utilized without adverse effects on their haematological and serum biochemical characteristics of broiler birds. The use of Annona muricata leaf extract at inclusion rate of $40 \mathrm{ml}$ of broiler diet (water) was seen to perform best than the rest and thus should be used instead of antibiotics since it has been discovered that some synthetic antibiotics are toxic and has residual effects in the consumers of these broiler birds.

\section{REFERENCES}

[1] B.D.Humphrey, N. Huang, K.C. Klasing, Rice expressing lactoferrin and lysozyme has antibiotic-like properties when fed to chicks. J. Nutr.132 (2002) 1214-1218.

[2] M.D. Newcomb, Herb as a source of nutrition versus herbs as a source of drugs. A matter of claims, biology and regulations(1999) pp. 295-3000. Proc. Of Altech's $15^{\text {th }}$ Annu, Sym, Biotech. In the feed industry. AltechTechinical Publications, Nottingham University Press. UK. 
[3] I.P. Ogbuewu, P.C. Jiwuba, C.T. Ezeokeke, M.C. Uchegbu, I.C. Okoli, M.U. Iloeje, Evaluation of phytochemical and nutritional composition of ginger rhizome powder. Int'l Journal of Agric. and Rural Dev. 17 (1) (2014) 1663-1670.

[4] I.P. Ogbuewu, M.C. Okehi, P.C. Jiwuba, Effect of phytobiotic (turmeric) supplementation on semen and blood characteristics of rabbits. CompClinPathol. (2017) DOI 10.1007/s00580-017-2452-0

[5] P.C. Jiwuba, F.O. Ahamefule, I.P. Ogbuewu, K. Ikwunze, Blood chemistry and haematology of West African Dwarf goats fed Moringaoleifera leaf meal (MOLM) in their diet. CompClinPathol.(2017) DOI 10.1007/s00580-017-2434-2.

[6] S.O. Moghdamtousi, M. Fadaeinasab, S. Nikzad, G. Mohan, H.M. Ali, H. Kadir,Annonamuricata (Annonaceae): A Review of Its Traditional Uses, Isolated Acetogenins and Biological Activities. Int J MolSci 16(7) (2015) 14825-14858.

[7] U. Usunobun, N.P. Okolie, O.G. Anyanwu, A.J. Adegbegi, M.E. Egharevba, Phytochemical screening and proximate composition of Annonamuricataleaves. Euro. J. Bot., Plant Sci. Phytol. 2(1) (2015) 18-28

[8] P.C. Jiwuba, E. Dauda, L.C. Ezenwaka, C.J.Eluagu, Replacement value of maize with sweet potato (Ipomoea batata) root meal on growth performance and haematogical characteristics of broiler starter birds. Archives of Current Research International 5(3) (2016) 1-7.

[9] AOAC, Association of official analytical chemists: Official Methods of Analysis. 6th Edition. Washington DC, USA(2000).

[10] R.G.D.Steele, J.H. Torrie, Principles and Procedure of Statistics: A biometrical approach: Mc Graw Hill Inc, New York USA(1980).

[11] D.B. Duncan, Multiple New Range and multiple F - Test. Biometrics, 11 (1955) 1 - 42.

[12] B.M. Ogle, L.E. Grivetti,Legacy of the chameleon: Edible wild plants in the Kingdom of Swaziland, Southern Africa. A cultural, ecological nutritional study. Part IV: Nutritional analysis and conclusion, Ecol. Food Nutr. 17 (1985) 41-64.

[13] E.U. Isong,U.I. Idiong, Comparative studies on the nutritional and toxic composition of three varieties of Leiantheraafricana, PlantsFood Hum. Nutr. 51 (1997) 79-84.

[14] A.A. Akindahunsi, S.O. Salawu, Photochemical screening and nutrient-anti-nutrient composition of selected tropical green vegetables,Afr. J. Biotech. 4 (2005) 497-501.

[15] F.O. Ahamefule, J.A. Ibeawuchi,F.C. Okoye, Blood biochemistry and haematology of West African Dwarf (WAD) bucks fed pigeon pea-cassava peel based diets. Journal Anim Vet Adv., 4 (12) (2005) 1016-1020.

[16] Z. Antunovic, J. Novoselec, H. Saurwein, M. Speranda, M. Vegara,V. Pavic, Blood metabolic profile and some of hormones concentration in ewes during different physiological status.Bulgarian Journal of Agricultural Science,17 (5),(2011) 687-695.

[17] T.W. Campbell,E.H. Cole, Avian Clinical Pathology in: Coles chick pathology. $4^{\text {th }}$ (Edn.). publ. EB Sainekers and $\operatorname{Co}(1986)$.

[18] I.P. Ogbuewu, M.C. Uchegbu,C.C. Ezuma,M.N. Opara, Physiological responses offinisher broilers to yaw peel, haematology and serum biochemistry. EJEAFCHE, 9(10) (2010) 1657-1664.

[19] J.G. Ross, G. Christie, E.G. Holiday, R.M. Jones, Haematological and blood chemistry comparison values for clinical pathology in poultry. Vet. Res, 102 (1979) 29-31.

[20] V.U. Oleforuh-Okoleh, H.M. Ndofor-Foleng, S.O. Olorunleke, J.O. Uguru, Evaluation of Growth Performance, Haematological and Serum Biochemical Response of Broiler Chickens to Aqueous Extract of Ginger and Garlic. Journal of Agricultural Science, 7 (4) (2015) 1916-9760.

[21] A.A. Njidda, J.U. Igwebuike, A.A. Ngoshe, A.O. Tijjani, Effect of substituting maize with graded levels of cane molasses on the performance of broiler finisher birds in the semi- arid region of Nigeria. J. Sustainable Agric. Environ., 8(1) (2006) 1-13.

[22] A.O. Owosibo, O.M. Odetola, O.O. Odunsi, O.O. Adejinmi, O.O. Lawrence-Azua, Growth, haematology and serum biochemistry of broilers fed probiotics based diets. African journal of agricultural research, 8(41) (2013) 5076-5081.

[23] A. Scott, Absorption of carbohydrate and protein metabolism. In: Duke's Physiology of Domestic Animals. 18 edn. (Swenson, M.J. edns). Cornell University Press Limited, London(1970).

[24] B.M. Mitruka, H.M. Rawnsley, Chemical biochemical and haematological references, values in normal experimental animal. Mason publishing, USA Inc. N.V (1977) 88-142.

[25] P.C. Jiwuba,D.O. Ugwu, O.E. Kadurumba,E. Dauda,Haematologicaland serum biochemical indices of weaner rabbits fed varying levels of dried Gmelinaarborealeaf meal. International Blood Research \& Reviews, 6(2) (2016) 1-8. 
Citation: J. Peter-Damian Chukwunomso et al., " Evaluation of Haematological and Serum Biochemical Characteristics of Annona muricata (Sour Sop) Leaf Extract on Broiler Birds ", International Journal of Research studies in Microbiology and Biotechnology, vol. 3, no. 4, p. 6-11, 2017. http://dx.doi.org/10.20431/ 2454-9428.0304003

Copyright: (C) 2017 Authors. This is an open-access article distributed under the terms of the Creative Commons Attribution License, which permits unrestricted use, distribution, and reproduction in any medium, provided the original author and source are credited. 